\title{
Greenhouse gas emissions associated with photovoltaic electricity from crystalline silicon modules under various energy supply options
}

\author{
N.H. Reich ${ }^{1 *, \dagger}$, E.A. Alsema1, W.G.J.H.M. van Sark ${ }^{1}$, W.C. Turkenburg ${ }^{1}$ and W.C. Sinke ${ }^{1,2}$ \\ 1 Department of Science, Technology and Society, Copernicus Institute, Utrecht University, Heidelberglaan 2, 3584 CS, Utrecht, \\ The Netherlands \\ 2 Energy Research Centre of the Netherlands (ECN), Petten, The Netherlands
}

\begin{abstract}
The direct and indirect emissions associated with photovoltaic (PV) electricity generation are evaluated, focussing on greenhouse gas (GHG) emissions related to crystalline silicon (c-Si) solar module production. Electricity supply technologies used in the entire PV production chain are found to be most influential. Emissions associated with only the electricity-input in the production of PV vary as much as $0-200 \mathrm{~g} \mathrm{CO}_{2}$-eq per $\mathrm{kWh}$ electricity generated by PV. This wide range results because of specific supply technologies one may assume to provide the electricity-input in PV production, i.e., whether coal-, gas-, wind-, or PV-power facilities in the "background" provide the electricity supply for powering the entire PV production chain. The heat input in the entire PV production chain, for which mainly the combustion of natural gas is assumed, adds another $\sim 16 \mathrm{CO}_{2}$-eq/kWh. The GHG emissions directly attributed to c-Si PV technology alone constitute only $\sim 1-2 \mathrm{~g} \mathrm{CO}_{2}$-eq/ $\mathrm{kWh}$. The difference in scale indicates the relevance of reporting "indirect" emissions due to energy input in PV production separately from "direct" emissions particular to PV technology. In this article, we also demonstrate the utilization of "direct" and "indirect" shares of emissions for the calculation of GHG emissions in simplified world electricity- and PV-market development scenarios. Results underscore very large GHG mitigation realized by solar PV toward increasingly significant PV market shares. Copyright (C) 2011 John Wiley \& Sons, Ltd.
\end{abstract}

\section{KEYWORDS}

global warming; energy transition; photovoltaic; $\mathrm{LCA}_{2} \mathrm{CO}_{2} ; \mathrm{PV}$ emissions

${ }^{*}$ Correspondence

N.H. Reich, Department of Science, Technology and Society, Copernicus Institute, Utrecht University, Heidelberglaan 2, 3584 CS, Utrecht, The Netherlands.

E-mail: N.H.Reich@uu.nl

Received 17 February 2010; Revised 5 August 2010

\section{INTRODUCTION}

The environmental performance of photovoltaic (PV) electricity generation has already been evaluated by a number of life cycle assessment (LCA) studies (see e.g., review of Azzopardi and Mutale [1] and references therein). Various impact categories are usually distinguished. One much-used category is that of global warming, sometimes reported as "carbon-footprint" due to $\mathrm{CO}_{2}$-eq greenhouse gas (GHG) emissions. These

\footnotetext{
${ }^{\dagger}$ Author is now to be reached under nils.reich@ise.fhg.de
}

emissions are most often reported per unit of generated PV electricity. For crystalline silicon (c-Si) solar modules, a range of $30-300 \mathrm{~g} \mathrm{CO}_{2}$-eq/kWh has been quoted so far [2-7]. It is not always made clear, however, that a large fraction of emissions stems from GHG's emitted by other technologies. If for example coal-fired power plants are assumed in the "background" to provide electricity input in $\mathrm{PV}$ production, high emissions are associated to PV electricity. On the other hand, if one assumes only renewable sources such as hydro- or wind-power or even PV electricity itself in the "background", emissions associated to PV are reduced very strongly. Another reason for deviating emissions in the various studies 
associated to PV electricity is that each study was conducted at a different time. Studies conducted in the 1990s showed higher emissions for PV than more recent ones, because PV production became more efficient meanwhile. However, the assumption on the "background" of the energy supply types in the particular study is of high significance, as we will show, which is not always (made) clear. In fact, one may find that emissions quoted for PV in very recent LCA studies are higher than those one may obtain with PV production data from the 1990, by just assuming "green" electricity in the "background" to power all PV production processes.

In this paper, we therefore follow an alternative approach to determine emissions associated with PV electricity, by considering a variety of energy supply options in the "background" on an individual basis. This enables the calculation of PV emissions for any share of energy supply options assumed in the "background". We limit ourselves to the evaluation of GHG emissions related to c-Si solar module technology. In addition, we evaluate by a simple calculation method the impact of our findings on the potential of solar PV to achieve deep GHG emission reductions.

The structure of this paper is as follows: first, calculation methods and used software are introduced (Section 2). Next, "direct" and "indirect" emission shares are calculated (Section 3) and linked to world electricity and PV market development scenarios, to determine its impact on cumulative emissions (Section 4). A discussion is presented in Section 5 , followed by conclusions in Section 6 .

\section{METHODOLOGY AND METHODS}

\subsection{Data source and used software}

In this study, we gathered detailing material- and energy consumption for $\mathrm{c}-\mathrm{Si}$ solar module production from the ecoinvent LCA database [8]. This data was processed using the SimaPro LCA software [9], in which scaling factors were introduced to analyze how different types of energy supply affect calculated PV emissions. Single scaling variables to linearly vary emissions (e.g., those related to electricity consumption) were needed due to the large number of database records. The many database records relate to all sub-processes applied to deliver auxiliary materials at early manufacturing stages (of e.g., PV production). Parameterized datasets were proven to be consistent with the original dataset by using scaling-factors of unity. A more detailed description of the parameterization approach is given elsewhere [10].

\subsection{Direct emission sources of crystalline silicon PV production}

The production of Si feedstock, the release of fluorinated process gases during PV production and the incineration of plastics during module recycling causes "direct" $\mathrm{CO}_{2}$ and $\mathrm{CO}_{2}$-eq emissions, i.e., irrespective of energy input in manufacture. In this study, we omit any further "direct" emission sources one may consider, such as emissions due to PV system operation and maintenance (e.g., cleaning tasks or PV destruction by accidental fires).

The following outlines how we calculated "direct" emissions of the listed emission sources. For Si feedstock production, we assumed the overall material balance to be sufficient in calculating "direct" $\mathrm{CO}_{2}$ emissions. Although processes and chemical reactions are much more complex in practice, only a stoichiometric fraction was considered, denoted by $f_{\mathrm{SiO} 2+\mathrm{C}}$, to account for the weight of combined $\mathrm{C}$ and $\mathrm{O}_{2}$ (see Equations (1) and (2)).

$$
\begin{gathered}
\mathrm{SiO}_{2}+\mathrm{C} \rightarrow \mathrm{Si}+\mathrm{CO}_{2} \\
m_{\mathrm{CO}_{2}, \mathrm{MG}-\mathrm{Si}}=f_{\mathrm{SiO} 2+\mathrm{C}} \cdot m_{\mathrm{Si}}=1.57 \cdot m_{\mathrm{Si}}
\end{gathered}
$$

in which $m_{\mathrm{CO} 2, \mathrm{MG}-\mathrm{Si}}$ is the mass of $\mathrm{CO}_{2}$ emitted per mass Si feedstock $m_{\mathrm{Si}}$. These "direct" emissions do notably not include any energy input and related emissions, because these are accounted for separately in the "indirect" emission category.

Concerning released process gases with high global warming potential (GWP) we used data of non-abated fluorinated process gas fractions as reported in literature $[11,12]$, with the aim to calculate "direct" emissions for the current PV technology status. One may argue, however, that in the future processes that use fluorinated gases such as $\mathrm{NF}_{3}$ or $\mathrm{CF}_{4}$ will be substituted by other processes that do not involve gases with high GWP. The same holds for the incineration of plastics during module recycling, as one may argue that "bio-plastics" may avoid these emissions in the future. Nowadays plastics, however, are produced mainly by crude oil (fossil) feedstock and incineration of plastics during PV module recycling and Si recovery is standard [13-15]. These emissions are therefore very similar to those of burning fossil fuels in, e.g., energy conversion. The plastics used in today's PV modules are usually ethylene vinyl acetate (EVA) copolymers for lamination and polyethylene terephthalate (PET) as well as polyvinyl fluoride (PVF) in back foils. Similarly to the $\mathrm{Si}$ feedstock calculation, mass balances were used to calculate the GHG emissions. Mass balances were simplified in that ideal incineration of PVF, PET, and EVA layers with oxygen from air was assumed (Equations 3-5).

$$
\begin{gathered}
\text { PVF : } 4\left(\mathrm{CH}_{2}-\mathrm{CHF}\right)+11 \mathrm{O}_{2} \\
\rightleftarrows \quad 8 \mathrm{CO}_{2}+6 \mathrm{H}_{2} \mathrm{O}+4 \mathrm{~F} \\
\text { PET : } 4\left(\mathrm{CO}-\mathrm{C}_{6} \mathrm{H}_{5}-\mathrm{CO}-\mathrm{O}-\mathrm{CH}_{2}-\mathrm{CH}_{2}-\mathrm{O}\right)+41 \mathrm{O}_{2} \\
\rightleftarrows \quad 40 \mathrm{CO}_{2}+18 \mathrm{H}_{2} \mathrm{O} \\
\text { EVA : } 4\left(\mathrm{CH}_{2}-\mathrm{CH}_{2}-\mathrm{CH}_{2}-\mathrm{CH}-\mathrm{O}-\mathrm{C}-\mathrm{O}-\mathrm{CH}_{2}\right)+29 \mathrm{O}_{2} \\
\rightleftarrows \quad 24 \mathrm{CO}_{2}+18 \mathrm{H}_{2} \mathrm{O}
\end{gathered}
$$


Table I. Range of PV electricity yields during entire PV system lifetime for various parameters.

\begin{tabular}{llccl}
\hline Symbol & Parameter & Single value & Value range & Dimension \\
\hline$\eta_{\text {Sys }}$ & Efficiency of PV & 15 & $15-25$ & $\%$ \\
$G_{\text {Array }}$ & Irradiation range & 1300 & $700-2500$ & $\mathrm{kWh} /\left(\mathrm{m}^{2} \mathrm{year}\right)$ \\
$t_{\text {System-lifetime }}$ & PV system lifetime & 30 & $20-40$ & $\mathrm{Years}$ \\
$Y_{\mathrm{PV}, \mathrm{P}}$ & Lifetime electricity yield & 31 & $12.9-84$ & $\mathrm{kWh} / \mathrm{W}_{\mathrm{p}}$ \\
Si use & Silicon mass per W & 6.1 & $2-6.1$ & $\mathrm{~g} / \mathrm{p}$ \\
- & "Electricity emissions" & 560 & $\sim 1-1000$ & $\mathrm{gCO}$-eq/ $/ \mathrm{kWh}$ \\
\hline
\end{tabular}

Analogous to Equation (2), the stoichiometric emission factors obtained for EVA-, PVF-, and PET-incineration, respectively, are $f_{\mathrm{PVF}}=2.05, f_{\mathrm{PET}}=2.28$, and $f_{\mathrm{EVA}}=2.34$.

Theoretically, the heat that is released when burning the plastic foils in the modules could be used for other purposes. However, we assumed this heat release to be of no practical value and therefore did not allocate this energy stream. One may further note that only a very small number of module recycling facilities are operational as of today. As a result, data on energy demands and emissions during recycling is scarce and we decided to not include energy demands and emissions apart of the "direct" emissions of the recycling process.

\subsection{Functional units and $P V$ energy yield range}

The basic units with which life cycle impacts of PV are expressed are usually emissions per installed PV capacity (in $\mathrm{kW}_{\mathrm{p}}$ ) or PV electricity produced over lifetime (in $\mathrm{kWh}$ ). The annual PV electricity production $\left(E_{\mathrm{PV} \text {,annual }}\right)$ is calculated by a PV surface area $\left(A_{\mathrm{PV}}\right)$, average system efficiency $\left(\eta_{\text {sys }}\right)$ and annual available irradiation $\left(G_{\text {annual }}\right)$, see Equation (6). From this, the total electricity production during lifetime $\left(\mathrm{t}_{\text {system-lifetime }}\right)$ can be calculated, for which degradation of PV efficiency with time $(t)$ was considered (see Equation (7)). No range was considered here as to avoid an even broader electricity yield range. We assume $80 \%$ of STC rated output after a lifetime of 25 years $(a=0.008$ in Equation (7)).

$$
\begin{aligned}
& E_{\mathrm{PV}, \text { annual }}\left(t_{\text {Year }}\right)=G_{\text {annual }} \cdot \eta_{\mathrm{sys}} \cdot A_{\mathrm{PV}} \quad\left[\mathrm{kWh}\left(\mathrm{t}_{\text {Year }}\right)\right] \\
& E_{\mathrm{PV}, \text { total }}=\sum_{t_{\text {Year }}=0}^{t_{\max }} E_{\mathrm{PV}, \text { annual }}\left(t_{\text {Year }}\right) \cdot\left(1-a \cdot t_{\text {Year }}\right) \quad\left[\mathrm{kWh}\left(\mathrm{t}_{\text {Year }}\right)\right]
\end{aligned}
$$

The energy yield of a terrestrial PV system can show a very wide range, primarily due to the differences in annual solar irradiation at different locations on earth, which spans $\sim 700-2500 \mathrm{kWh} /\left(\mathrm{m}^{2} \mathrm{yr}\right)$ considering, e.g., North of Europe and Saharan Africa [16]. Also varying conversion efficiencies can be assumed (for c-Si PV currently $\sim 15$ $20 \%$ ). Inverter efficiencies, shadow-patterns, cabling losses, and other, minor system efficiency aspects can further broaden the range of PV electricity yields. We therefore considered a wide range for the overall PV system performance and irradiation, which resulted in an even wider range of PV electricity yield $\left(12.6-84 \mathrm{kWh} / \mathrm{W}_{\mathrm{p}}\right.$, see Table I). Also a single value for each parameter is considered, as to account for a "representative" terrestrial PV system. We aimed to select reasonable averages of current c-Si PV technology for efficiency (15\%), lifetime (30 years), and degradation (to $80 \%$ of rated capacity after 25 years), which resulted in the lifetime electricity yield of $\sim 31 \mathrm{kWh} / \mathrm{W}_{\mathrm{p}}$ assuming $1300 \mathrm{kWh} / \mathrm{m}^{2}$ annual solar irradiation. Also a range in Si material use was included (see Table I), because of the high influence of Si material use on energy demand, and, as a result, on emissions one may attribute to PV. We started our study with the current average Si-use of $6.1 \mathrm{~g} / \mathrm{W}_{\mathrm{p}}$ but considered a large reduction down to $2 \mathrm{~g} / \mathrm{W}_{\mathrm{p}}$ related to future PV technology development (Section 4).

Finally, also GHG emissions associated to electricity are listed in Table I. The high value of $\sim 1000 \mathrm{~g} \mathrm{CO}_{2}$-eq $/ \mathrm{kWh}$ corresponds to coal-fired electricity generation without CCS (Carbon dioxide Capture and Sequestration). The low value corresponds to "direct" PV emissions (sub-section 3.1 ) and the single value of $560 \mathrm{~g} \mathrm{CO}_{2}$-eq/ $\mathrm{kWh}$ represents the average $\mathrm{CO}_{2}$-eq emission of electricity used in this study. Here, we selected the European electricity footprint at "medium voltage UCTE" in ecoinvent (including indirect emissions from fossil fuel systems such as $\mathrm{NO}_{2}$ and $\mathrm{CH}_{4}$, converted into $\mathrm{CO}_{2}$-eq).

\section{SOLAR PV GHG EMISSIONS PER kWh}

\section{1. "Direct" emission sources of PV production}

The $\mathrm{CO}_{2}$ emissions of $\mathrm{Si}$ feedstock production depend linearly on the mass of silicon produced, see Equation (2). In the Si-consumption of solar cell production, however, not only the silicon material contained in the cells but also silicon material losses (mainly from sawing) are included. As silicon material waste (mainly from sawing) is commonly and commercially re-used for PV and nonPV purposes, "direct" emissions related to Si feedstock production were assumed to be only related to that amount of Si-material contained in the cells. We therefore assumed $3 \mathrm{~g} / \mathrm{W}_{\mathrm{p}}$, which with the $6.1 \mathrm{~g} / \mathrm{W}_{\mathrm{p}}$ average Si use (Table I) implies we assumed $\sim 50 \%$ of mainly sawing loss. The $3 \mathrm{~g} /$ 
$\mathrm{W}_{\mathrm{p}}$ translate into the wide "direct" $\mathrm{CO}_{2}$-eq emission range of $0.06-0.4 \mathrm{~g} \mathrm{CO}$-eq $/ \mathrm{kWh}$ with the considered PV electricity yield range. For the "representative" PV system with $31 \mathrm{kWh} / \mathrm{W}_{\mathrm{p}}$ yield over the lifetime, "direct" GHG emissions related to $\mathrm{Si}$ feedstock production are $0.16 \mathrm{~g}$ $\mathrm{CO}_{2}$-eq/kWh.

Fluorinated process gases such as $\mathrm{CF}_{4}$ and $\mathrm{C}_{2} \mathrm{~F}_{6}$ are used in reactor chamber cleaning, edge isolation, and phosphorus silicate glass (PSG) removal and could possibly be applied in dry texturing processes in the future $[11,12]$. The public life cycle inventory (LCI) data of Alsema and De Wild-Scholten suggests $\sim 18 \mathrm{~g} \mathrm{CO}_{2}$-eq/ $/ \mathrm{W}_{\mathrm{p}}$ as an average of industrial $\mathrm{c}-\mathrm{Si}$ production overall, but rather low process gas utilization $(\sim 70 \%)$ and abatement efficacy $(95 \%)$ is assumed. The $\sim 18 \mathrm{~g} \mathrm{CO}_{2}$-eq/ $/ \mathrm{W}_{\mathrm{p}}$ can therefore be argued to represent a rather conservative estimate for the current industry-average of c-Si production technology. It appears more industry data are needed to ensure that more optimistic data, which one may anticipate, will also be reported appropriately. One may think here about, e.g., wet rather than dry processing for the processing steps texturing, PSG removal, and edge isolation, respectively, with wet processing not involving any F-gases and hence no F-gas emissions. Also edge isolation by laser can avoid the use of F-gases. If dry processing routes will take hold, however, also the substitution of F-gases by $\mathrm{F}_{2}$ (generated on-site) may allow for zero "direct" emissions. In summary, viable c-Si PV production processes exist (also operational in the industry) with which F-gas emissions are avoided entirely. With the PV electricity yield ranges assumed in this study, the F-gas emissions would therefore translate into either zero, or in case of the $\sim 18 \mathrm{~g} \mathrm{CO}_{2}$-eq/ $\mathrm{W}_{\mathrm{p}}$ industry average (as of year 2007), into 0.2-1.4 $\mathrm{g} \mathrm{CO}_{2^{-}}$ $\mathrm{eq} / \mathrm{kWh}$. For the "representative" PV system emissions are zero or $0.6 \mathrm{~g} \mathrm{CO}_{2}$-eq $/ \mathrm{kWh}$.

The alternatives of "bio-plastics" and "plastic-free" encapsulation are not (yet) viable or "practically feasible" for state-of-the-art PV production. Plastic consumption for PV module encapsulation was, therefore, also taken from the LCI data presented by De Wild-Scholten and Alsema [17], which is $1 \mathrm{~kg} / \mathrm{m}^{2}$ EVA, $0.5 \mathrm{~kg} / \mathrm{m}^{2} \mathrm{PVF} / \mathrm{PET}$, and $0.3 \mathrm{~kg} / \mathrm{m}^{2}$ other per $\mathrm{m}^{2} \mathrm{PV}$ module area. With weighted emission factors and assuming an average emission factor for "other" plastics, the "direct" emissions total $5.17 \mathrm{~kg}$ of $\mathrm{CO}_{2}$-eq per $\mathrm{m}^{2}$. With the $\mathrm{PV}$ energy yield range we consider (see Table I) this total emission translates into $0.25-3.8 \mathrm{~g} \mathrm{CO}_{2}-\mathrm{eq} / \mathrm{kWh}$ generated PV electricity. For the "representative" PV system that has $31 \mathrm{kWh} / \mathrm{W}_{\mathrm{p}}$ lifetime electricity yield and $15 \%$ efficiency "direct" emissions due to incinerating plastics of $1.1 \mathrm{~g} \mathrm{CO}_{2}$-eq/kWh result. Although we assume state-of-the-art recycling processes here, it is worthwhile to recognize that the used techniques to recycle PV modules may change considerably in the next decennia. Due to the very long lifetime of PV systems, the recycling techniques of those $\mathrm{PV}$ systems taken into operation today may therefore differ substantially, i.e., if the modules will, e.g., be mechanically treated rather than that the plastics will be incinerated without causing any of the "direct" emissions calculated here. Also it must be noted that not included in these emissions are any "indirect" sources as energy-input related to the disassembly of the entire system and transport of the various components to recycling facilities.

Summarizing total direct emissions, $1.26 \mathrm{CO}_{2}$-eq $/ \mathrm{kWh}$ are obtained for the "representative" PV system that has $31 \mathrm{kWh} / \mathrm{W}_{\mathrm{p}}$ lifetime electricity yield, without F-gases. Taking F-gas emissions into consideration still shows the incineration of plastics to constitute the major emission share ( $\sim 60 \%$ ), but $31 \%$ are related to F-gas emission, only $9 \%$ is due to $\mathrm{Si}$-feedstock production.

\subsection{PV-emissions for different electricity-supply options}

The PV module production processes were categorized into production of $\mathrm{Si}$ feedstock, Si-ingots, -wafers, -cells, and -modules and analyzed individually for parameterized "electricity emissions". In addition, "transport" emissions were assessed for each production category individually. Electricity related emissions were found to constitute the major share of $\sim 50 \%$ to overall emissions, whereas transport related emissions were found to be insignificant according to the used ecoinvent data (see Figure 1, with transport $<1 \%$ overall). The differences of cumulative emissions (left panel) were used to calculate
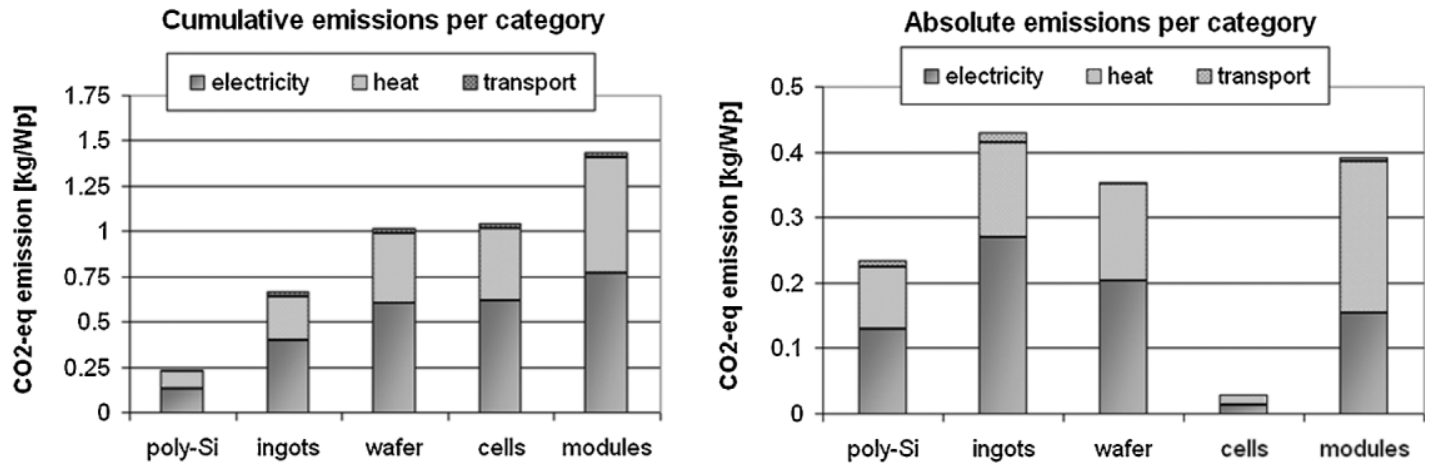

Figure 1. Share of "electricity", "heat", and "transport" in the PV module production chain. 


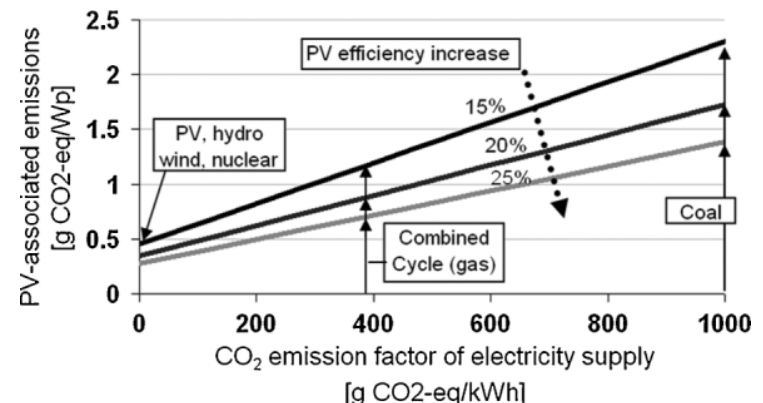

Figure 2. The $\mathrm{CO}_{2}$-eq emissions per $W_{p}$, of silicon $P V$ modules with monocrystalline cells $\left(6.1 \mathrm{~g} / \mathrm{W}_{\mathrm{p}}\right.$ Si use overall) for different emission factors of the 'background' electricity supply. Three lines are depicted corresponding to a PV efficiency of 15,20, and $25 \%$, respectively.

absolute emissions per category (right panel) both in $\mathrm{kg} /$ $\mathrm{W}_{\mathrm{p}}$. The "direct" emissions, see sub-section 3.1, are insignificant in that these are too small to be visible, and the remaining emission shares can be denoted "heat", as these are mainly caused by combustion of natural gas and oil to provide heat energy input. For demonstration purposes, the PV module considered here was modeled assuming the single parameter values in Table I, considering mono crystalline cells and the detailed PV production data taken from the LCI data of De Wild-Scholten and Alsema [17].

With emissions attributed to electricity input in PV production representing the major share, these were analyzed more in depth, for different electricity supply options. The same PV module used in Figure 1 was therefore modeled again, now differentiating electricity supply options that one may assume in the "background". Results are shown in Figure 2. Assuming electricity is provided by coal-fired facilities in the "background", very large emission of $\sim 1 \mathrm{~kg} \mathrm{CO}_{2}$-eq are related to PV when the production of $1 \mathrm{~W}_{\mathrm{p}}$ consumes $1 \mathrm{kWh}$ electricity (right-most $x$-axis value in Figure 2). In this case, fairly large $\mathrm{CO}_{2}$-eq emissions of about $1.5-2.5 \mathrm{~kg} \mathrm{CO}$-eq/ $/ \mathrm{W}_{\mathrm{p}}$ are related to the $\mathrm{PV}$ module produced ( $\mathrm{y}$-axis in Figure 2). Combined Cycle
(CC) gas-fired power plants have emissions just below $400 \mathrm{~g} \mathrm{CO}_{2}$-eq $/ \mathrm{kWh}$, which relates about $0.75-1.2 \mathrm{~kg} \mathrm{CO}_{2^{-}}$ eq/ $\mathrm{W}_{\mathrm{p}}$ to the produced PV module. Assuming low-carbon electricity-supply technologies such as PV, hydro, nuclear, or wind in the entire production chain reduces the "carbon footprint" to approximately $0.25-0.5 \mathrm{~kg} \quad \mathrm{CO}_{2}-\mathrm{eq} / \mathrm{W}_{\mathrm{p}}$. Different PV efficiencies affect the slope of impact of different electricity emission-factors. Finally, note that for the case of, e.g., PV- or wind-power as electricity supply, hence under virtually zero "electricity-emissions", the remaining GHG emission are almost entirely related to heat-input, because transport related emissions are relatively small and "direct" emissions insignificant (see Figure 1 and sub-section 3.1). It must be noted that these emissions are attributed only to the PV module. The BOS components and inverter, which are obviously needed in a PV system too, have not been included in this analysis.

To calculate emissions per unit of PV electricity based upon results shown in Figure 2 is a straightforward exercise, because only the PV electricity yield needs to be accounted for. For the "representative" PV yield of $31 \mathrm{kWh} / \mathrm{W}_{\mathrm{p}}$ one can, for example, calculate $\sim 16 \mathrm{~g} \mathrm{CO}_{2}$-eq/ $\mathrm{kWh}$ related to heat input in PV production. Due to the very wide electricity yield range one may consider, however, emission ranges associated to $\mathrm{PV}$ generated electricity usually vary. For the $12.6-84 \mathrm{kWh} / \mathrm{W}_{\mathrm{p}}$ range of $\mathrm{PV}$ yields, we assumed here, "green" or nuclear electricity input in $\mathrm{PV}$ production gives $0.06-1.6 \mathrm{~g} \mathrm{CO}_{2}$-eq $/ \mathrm{kWh}$ whereas coal electricity in the "background" gives 30-200 $\mathrm{g} \mathrm{CO}_{2}$-eq/ $\mathrm{kWh}$ associated to PV.

\subsection{Comparison of "direct" and "indirect" emissions in PV production}

A graphical comparison of the "direct" and "indirect" emission sources as calculated afore is shown in Figure 3. Irrespective of which specific PV system efficiency or annual irradiation is assumed (see Table I and normalized $x$-axis in Figure 3), the fraction of "direct" emissions is at

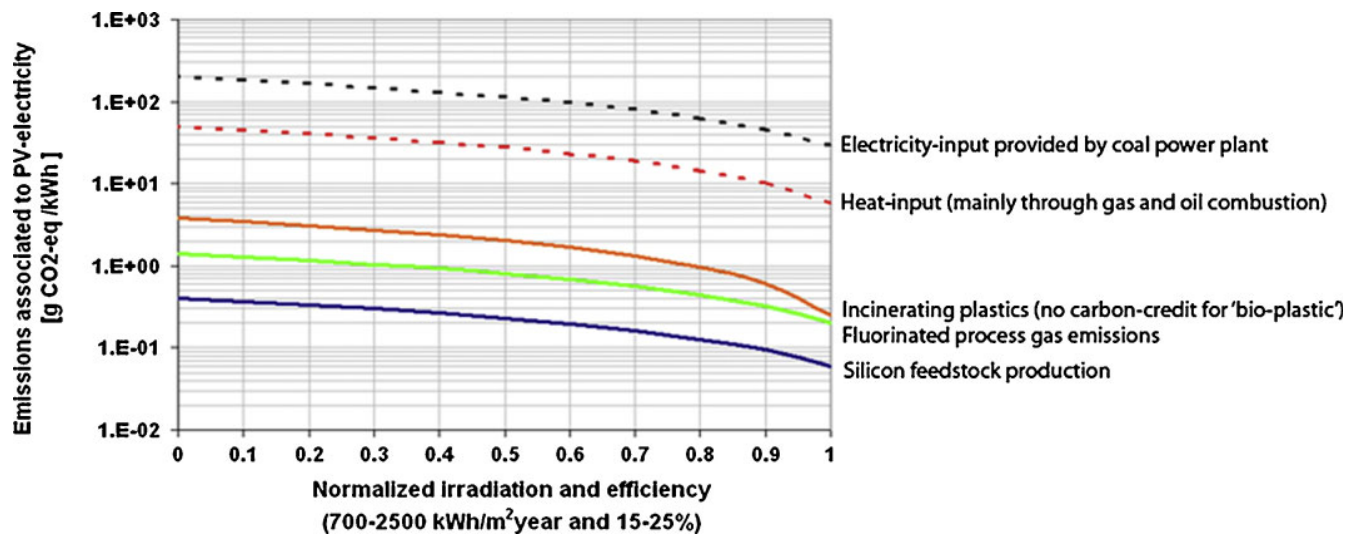

Figure 3. Comparing direct and indirect $\mathrm{CO}_{2}$-eq emission or $\mathrm{c}-\mathrm{Si} \mathrm{PV}$, the normalized $\mathrm{x}$-axis depicts the broad $\mathrm{PV}$ electricity yield range of 12.4-84 $\mathrm{kWhAV}_{\mathrm{p}}$ one may assume. 
least one order of magnitude lower than "indirect" emissions. It clearly shows the most significant fraction of emissions is "indirect", indicating the importance to report these emissions separately.

In a similar comparison, seven environmental impact categories frequently distinguished by the LCA community were considered in our study. If "green" electricity rather than the current average electricity supply was assumed, environmental impact of PV is reduced strongly in all LCA categories, although the decrease is somewhat smaller for the "human toxicity" and "eutrophication" categories (Figure 4).

\section{PV MARKET SHARE PROJECTIONS UP TO THE YEAR 2050 AND CORRELATED EMISSION AVOIDANCE}

In our study, we also evaluated $\mathrm{CO}_{2}$-eq emissions of world electricity consumption related to a number of PV market development scenarios. To this end, arbitrary PV market size was modeled by S-shaped market growth for the annually installed PV capacity $P_{\mathrm{PV}-\text { cap }}(t)$, modeled using Equation (10).

$$
P_{\mathrm{PV}-\text { cap }}(t)=\frac{P_{\mathrm{PV}-\text { cap, max }}}{1+e^{-\left(z+g\left(t+t_{0}\right)\right)}} \quad[\mathrm{TW} / \text { year }]
$$

where $g$ is the rate of growth modeled for time $t$ (year), with starting time $t_{0}$ set to year 2010, $P_{\mathrm{PV} \text {-cap,max }}$ is the maximum PV capacity that results for $t \gg t_{0}$ and the coefficient $z$ scales modeled annual PV capacity installed (i.e., varying $\mathrm{z}$ vertically shifts the entire modeled line of $\left.P_{\mathrm{PV} \text {-cap }}(t)\right)$.

In order to compare modeled world electricity demands with modeled PV capacities in a simple way, a number of significant simplifications need to be made. First and foremost we assumed an average annual PV yield of only $1000 \mathrm{kWh} /\left(\mathrm{kW}_{\mathrm{p}}\right.$.year $)$ to calculate PV electricity market shares. Although this low yield can be argued to considerably underestimate "average world PV yield", this assumption is very practical: It allows a direct visual comparison of modeled world electricity demand with world PV capacity, shown in Figure 5 (upper panel). In this figure, the accumulated PV capacity installed is plotted on the left $y$-axis, in the unit GW. With the assumed average yield of PV being $1000 \mathrm{kWh} /\left(\mathrm{kW}_{\mathrm{p}}\right.$.year $)$, this accumulated world PV capacity in $\mathrm{GW}_{\mathrm{p}}$ translates to the unit $\mathrm{TWh} /$ year PV electricity generated, the scale with which annual world electricity demand is indicated on the right axis.

The PV capacity that needs to be installed annually, in order to reach the shown cumulative installed PV capacity, is also plotted in Figure 5 (lower panel), together with the PV market share based upon the assumed average $1000 \mathrm{kWh} / \mathrm{kW}_{\mathrm{p}}$ yield. Parameter sets used to model PV market development scenarios shown in Figure 5 are listed in Table II. The growth projections are denoted by letters A through $\mathrm{D}$ and illustrate corresponding emission reductions. Note that we do not explicitly intend to speculate on likely or unlikely PV market development. For a comparison of what we considered as PV markets here, however, also data as reported by the IEA World Energy Outlook 2008 [18] was included in Figure 5, which suggests $220 \mathrm{GW}_{\mathrm{p}}$ installed world PV capacity in 2030 and which is therefore essentially lower than scenario D. Also the EPIA/Greenpeace figure stated in the "Solar Generation V - 2008" report [19] is included, which with $1.84 \mathrm{TW}_{\mathrm{p}}$ cumulative installed PV capacity projected for year 2030 is about one order of magnitude higher than the IEA figure. Finally, also a projection stated by the US based company named "1366 Technologies Inc." is included (stating 5.5 $\mathrm{TW}_{\mathrm{p}}$ installed world PV capacity "as a base" with annual production of $1.1 \mathrm{TW}_{\mathrm{p}}$ in 2035 [20]), which in year 2035 is essentially equal to scenario B. To guide the eye also the annual PV production growth of the past 15 years [21,22] extrapolated into the future is depicted (dotted line), essentially showing that PV production growth has to flatten.

Next, the emissions of world electricity consumption and the emissions of world PV production were calculated

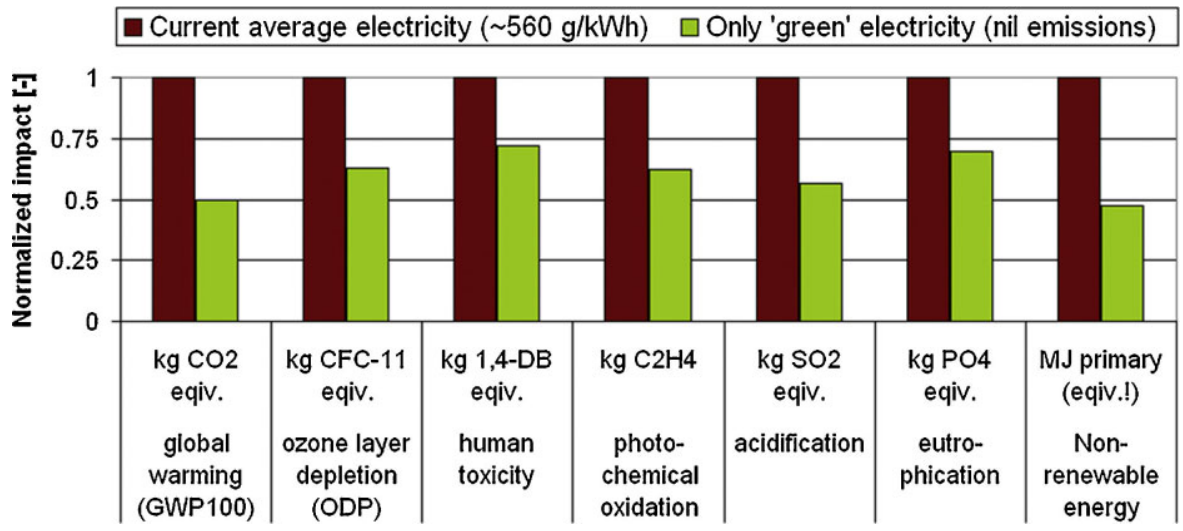

Figure 4. Normalized environmental impact associated to a solar PY module for the current average of electricity-emissions $(560 \mathrm{~g}$ $\mathrm{CO}_{2}$-eq/kYVli) and "green" electricity consumed in PV module production. 

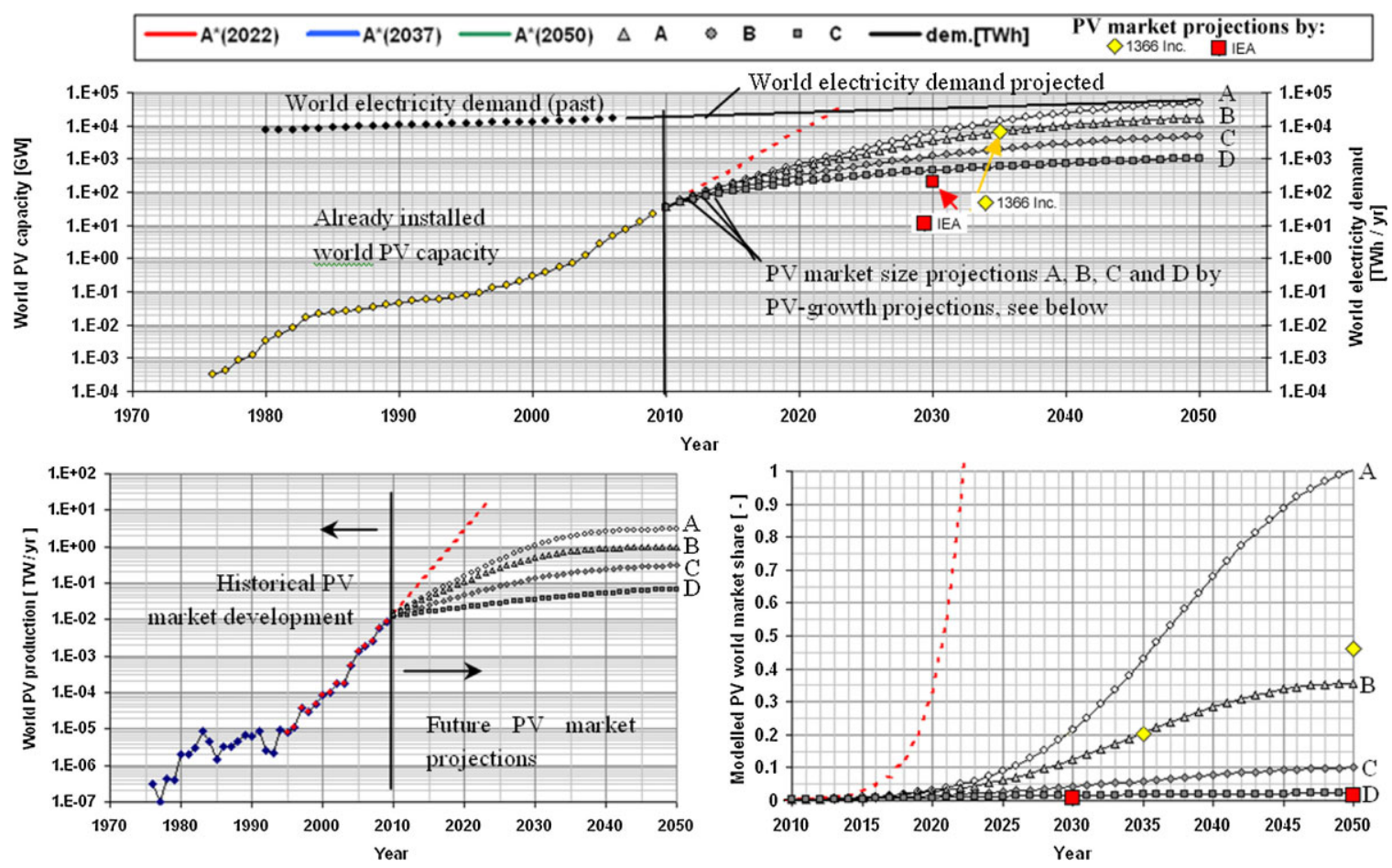

Figure 5. Historic PV market growth and projected PV market scenarios. See text for a detailed explanation.

for each scenario, based upon modeled PV market shares. The calculation started in year 2010 with the average of now $600 \mathrm{~g} \mathrm{CO}_{2}$-eq/kWh associated to global "electricity emission", as reported by the IEA [18], which is slightly higher than the figure for Europe we used in sub-section 3.2. This global emission figure was kept constant for the amount of electricity not delivered by PV. The combined figure is of course showing substantially reduced emissions towards larger PV market shares. To also account for the emissions caused each year by the production of the PV systems is of course of relevance, which under varying "electricity emissions" are shown in the left panel of Figure 6. As shown, emissions related to PV production become much larger, the more rapid PV market development will be, but emissions due to the world electricity consumption decrease even faster, as shown in the center panel of Figure 6, because emissions associated to the world electricity consumption of course decrease with increased PV market shares. As one may expect, we find cumulative world CO2-eq emissions to be lower overall, if $\mathrm{PV}$ market growth is stronger and, as a result, PV market share is larger. This is reflected in the cumulative emissions shown in the right panel of Figure 6.

Interestingly, one can see that annual emissions due to 3 TW/year PV production in 2050 (scenario A) are only somewhat larger than production of $1 \mathrm{TW} /$ year in 2050 (scenario B). This is due to the fact that the $1.5 \mathrm{Gt} \mathrm{CO} 2$-eq/ year emission of $3 \mathrm{TW} /$ year $\mathrm{PV}$ production is caused entirely by heat input and transport, because PV electricity share is (in theory) $100 \%$ and electricity-related emissions are no longer of relevance (Figure 2). To keep the calculation of emissions shown in Figure 6 simple and transparent, the previously assessed PV module (15\% efficiency, $6 \mathrm{~g} / \mathrm{W}_{\mathrm{p}}$ silicon use, see Figures 1 and 2) was assumed. Further, here we assumed only a single lifetime value of 20 years and also assumed no degradation in PV power output during these 20 years, because this allowed the calculation to be performed using a simple spreadsheet model. To account for technological progress we decided to consider in addition a gradually decreasing $\mathrm{Si}$ use from now $6 \mathrm{~g} / \mathrm{W}_{\mathrm{p}}$ down to either 4 or $2 \mathrm{~g} / \mathrm{W}_{\mathrm{p}}$ in the year 2050 . This would downscale emissions in the production

Table II. Parameters used to model PV market scenarios.

\begin{tabular}{llccr}
\hline Scenario & $\begin{array}{c}\text { Growth } \\
\text { rate g }\end{array}$ & Parameter $z$ & $\begin{array}{c}\text { P PV-cap,max } \\
\text { (TW/yr) }\end{array}$ & $\begin{array}{r}\text { World PV share } \\
\text { in year 2050 (\%) }\end{array}$ \\
\hline A & 0.2346 & -5.3 & 3 & 100 \\
B & 0.50 & -5.6 & 1 & 35 \\
C & 0.28 & -5.6 & 0.333 & 10 \\
D & 0.20 & -5.0 & 0.1 & 1 \\
\hline
\end{tabular}



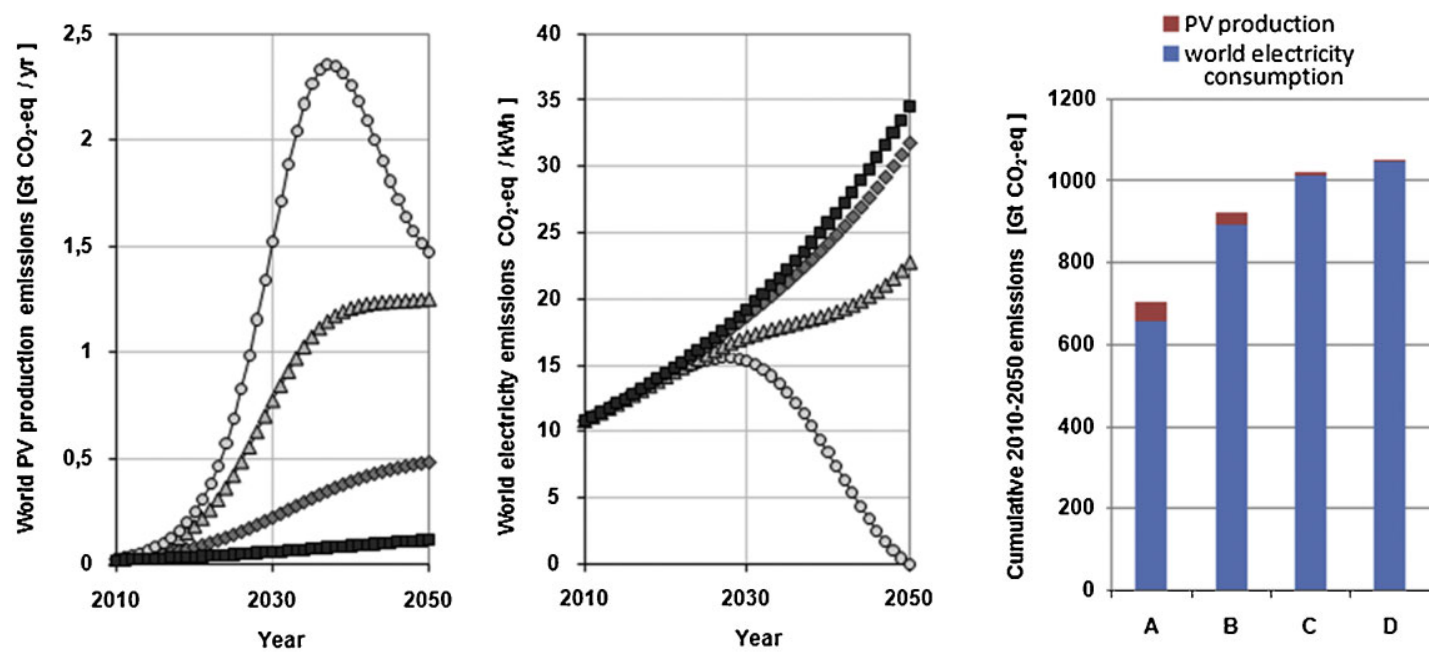

Figure 6. World $\mathrm{CO}_{2}$-eq emissions of world electricity consumption related to the modeled PV market scenarios (Figure 5 and Table II with Equation (10)).

categories poly-Si, ingot-, and wafer-production, respectively, attributed to electricity- and heat-input (Figure 1 for specific emission shares). The corresponding, cumulative net emission totals for this case of a further advancing PV production technology are listed in Table III, for scenarios A-D.

The listed net emission avoidance, for example $-407 \mathrm{Gt}$ $\mathrm{CO}_{2}$-eq of scenario $\mathrm{A}$, results from the $-456 \mathrm{Gt} \mathrm{CO}_{2}$-eq avoided emissions by $\mathrm{PV}$ electricity use rather than the current average electricity emission (which causes $600 \mathrm{~g}$ $\mathrm{CO}_{2}$-eq/kWh), which is offset by relatively large $\mathrm{CO}_{2}$-eq emissions of $+49 \mathrm{Gt}$ owed to $\mathrm{PV}$ production. One can observe for each scenario that emissions attributed to PV production decrease strongly with lower Si use, however, compared to overall emission avoidance this further decrease is small. In conclusion, PV market size and thereby avoided emissions are more decisive than emissions attributed to PV production. Rather than considering so-called "net energy benefit" or "marginal energy supply" worries, as expressed in literature [23], one should therefore consider and highlight that faster PV market growth is very beneficial to avoid emissions in the first place.

\section{DISCUSSION}

The emissions related to energy input in PV production are denoted "indirect" emissions and differentiated from "direct" emissions particular to PV production. This separation of "direct" and "indirect" emission sources for PV-electricity is fairly similar to a common distinction made for fossil-fuel fired energy conversion systems. We translated this terminology to PV technology, although virtually no emissions during PV operation occur. The introduction of "direct" PV emissions makes sense nonetheless in that during PV production emissions occur that are "directly" related to PV technology alone: irrespective of an energy-input served by any energy technology with very own emission patterns.

As the "direct" emission sources of c-Si solar module production we identified for GHG emissions the production of Si feedstock (reduction of quartz and carbon to $\mathrm{Si}$ and $\mathrm{CO}_{2}$ ), the incineration of plastics incorporated into today's PV modules during module recycling, and finally the release of fluorinated process gases into the atmosphere that have high GWP. We omitted any further "direct" emission source one may consider, such as emissions due

Table III. Avoided emissions of PV electricity and emissions attributed to PV production assuming a gradually decreasing Si material demand in PV production. Emissions avoided due to virtually emission-free PV electricity use are denoted by " -" and emissions attributed to PV production are denoted by "+".

\begin{tabular}{lcccc}
\hline \multicolumn{4}{c}{ Cumulative emission balance years 2010-2050 (Gt $\mathrm{CO}_{2}$-eq) } \\
Emission attributed \\
to PV production
\end{tabular}


to maintenance or destruction of PV by accidental fires. Emissions for Si feedstock production are found to be very small $\left(\sim 0.16 \mathrm{~g} \mathrm{CO}_{2}\right.$-eq $\left./ \mathrm{kWh}\right)$, but "direct" emissions related to the release of fluorinated process gases $(\sim 0.6 \mathrm{~g}$ $\mathrm{CO}_{2}$-eq/kWh) and in particular due to the incineration of plastics $\left(\sim 1.1 \mathrm{~g} \mathrm{CO}_{2}\right.$-eq/kWh $)$ may be perceived noteworthy. For the fluorinated process gas emissions, however, viable production options exist (also implemented into industrial, large scale PV production) that do not use Fgases at all. Wet rather than dry processing as well as laser processes may substitute F-gas use entirely in the future, and also enhanced process gas utilization or increased abatement, respectively, may lower related emissions further than the $\sim 0.6 \mathrm{~g} \mathrm{CO}_{2}$-eq/kWh we find for literature data on c-Si PV status as of year 2007. Also concerning the incineration of plastics, one may argue that emissions of $\sim 1.1 \mathrm{~g} \mathrm{CO}_{2}$-eq $/ \mathrm{kWh}$ could be reduced substantially. For one, "bio-plastics" made from organic feedstock that takes $\mathrm{CO}_{2}$ from the atmosphere, whilst not causing too much $\mathrm{CO}_{2}$-eq emissions due to, e.g., fertilizer-consumption and transport-demands, could possibly imply an almost neutral $\mathrm{CO}_{2}$ mass balance. Also PV modules that have the plastics incorporated into module frames rather than in between cells are being developed, which in turn implies that mechanical treatment rather than incineration is likely, essentially eliminating airborne GHG emissions should such concepts gain hold. The three "direct" emission sources of F-gases, plastic incineration and Si-feedstock production altogether, however, contribute at present only $\sim 2 \mathrm{~g} \mathrm{CO} 2$-eq/kWh, and not considering F-gases only $\sim 1 \mathrm{~g}$ $\mathrm{CO} 2-\mathrm{eq} / \mathrm{kWh}$. This GHG emission figure is thus at least a factor 10 lower compared to $\sim 30-100 \mathrm{~g} \mathrm{CO} 2-\mathrm{eq} / \mathrm{kWh}$ reported in previous, recent LCA studies, which considers very similar PV technology data, but include large shares of indirect, energy-input related emissions not separately specified or differentiated.

Already a number of previous studies aimed at improved assessment methodologies of PV related emissions. Richards and Watts [24] proposed to focus the yield ratios rather than energy payback times (EPT) as to avoid the widespread public misconception that PV would not deliver back as much energy as was needed in production. Although a plausible and also interesting concept, such an approach does not directly focus upon emissions attributed to PV electricity. Concerning emissions, in particular Krauter and Rüther [25] showed that a variety of sinks and sources must be considered, in order to set up sound emission balances when associating emissions to $\mathrm{PV}$ electricity. One problem of balancing emissions, however, is that one has to include the energy market and needs to "predict" future emissions of this market, which adds uncertainty. The advantage of the proposed differentiation of "direct" and "indirect" emissions is that complexity is reduced, because it is not necessary for individual LCA analyses to forecast future developments. Nonetheless, first approach future PV market development scenarios were presented in this study as to show that from an environmental perspective so-called "net energy benefit" considerations represent a needless worry. Here, Lysen and Daey Ouwens [23] argued that too fast PV market growth would lead to increased emissions, due to so-called "negative net energy benefit". We find, however, that The lower the aggregated GHG emissions in principle the stronger PV market growth will be.

Finally, it has to be noted that only a very simplified analysis regarding world GHG emission avoidance for projected PV market shares was presented here. Future research is needed that takes into consideration a broad variety of further effects of relevance. For one, other (renewable) electricity technologies are likely to gain significant market shares in the near- and mid-term future (amongst which, e.g., wind- and concentrating solar power). However, as such technologies also have a low carbon footprint their penetration will not significantly change (negatively) the results of our analysis. Another important issue not addressed in our analysis, however, is the "matching" of the daily and seasonal patterns of electricity generation by PV on the one hand with electricity demand on the other hand. This matching problem may raise the need for back-up power supply in the form of electricity storage systems or even standby operation of thermal power plants. In case the solution is sought in thermal backup power using fossil fuels this will lead to somewhat lower decrease in carbon emissions from the total electricity supply system with increasing PV shares. Storage systems, on the other hand, would have much less or virtually zero impact on carbon emission, but conversion losses would require higher installed electricity generation capacities.

\section{SUMMARY AND CONCLUSIONS}

It is proposed to separately report "direct" and "indirect" sources of emissions in future environmental studies to increase the transparency of emissions associated with PV electricity. The "indirect" emissions, related to energy input in c-Si PV production, constitute the major share in GHG emissions. On top of heat supply that is mainly provided by the combustion of natural gas or oil $(\sim 16 \mathrm{~g}$ $\mathrm{CO}_{2}$-eq/kWh) in particular the different electricity supply options that can be assumed to power PV production cause wide ranges to be projected onto PV electricity. Assuming for example coal electricity to provide electricity input in $\mathrm{PV}$ production relates $30-200 \mathrm{~g} \mathrm{CO}$-eq/kWh to $\mathrm{PV}$ electricity, whereas assuming electricity generated by PV itself or wind-power virtually eliminates emissions entirely. Emissions attributed to PV technology alone are found to be $\sim 2 \mathrm{~g} \mathrm{CO}_{2}$-eq/ $\mathrm{kWh}$ only, taking $\mathrm{Si}$ feedstock production, fluorinated process gas emissions, and incineration of plastics during module recycling together. Considering no F-gases are used at all, which is the case for many industrial $\mathrm{PV}$ production facilities, this figure is reduced to about $\sim 1 \mathrm{~g} \mathrm{CO}_{2}$-eq/kWh. Finally, we calculate GHG emission mitigation as a function of PV market size 
for simplified world electricity and world PV market scenarios. Differentiating "direct" and "indirect" PV emissions is found to greatly facilitate these calculations. Obtained results underscore the very large world GHG emission mitigation potential that can be realized with increasingly significant PV market shares ahead, with in particular faster PV market development leading to substantially lower emissions.

\section{ACKNOWLEDGEMENTS}

The first author wishes to express his deep gratitude to $\mathrm{Dr}$ Richard Louis Rogers.

\section{REFERENCES}

1. Azzopardi B, Mutale J. Life cycle analysis for future photovoltaic systems using hybrid solar cells. Renewable and Sustainable Energy Reviews 2010; 14(3): 1130-1134.

2. Alsema EA, Wild-Scholten MJd. Reduction of the environmental impacts in crystalline silicon module manufacturing. In Proceedings of 22nd European Photovoltaic Solar Energy Conference, Willeke G, Ossenbrink H, Helm P (eds). WIP-Renewable Energies: Munich, Germany, 2007; 829-836.

3. Fthenakis V, Alsema EA. Short communication: accelerated publication photovoltaics energy payback times, greenhouse gas emissions and external costs: 2004-early 2005 status. Progress in Photovoltaics: Research and Applications 2006; 14(3): 275-280.

4. Hagedorn G. CO2-reduktions-potential photovoltaischer systeme. Sonnenenergie 1990; 1(1): 12-15.

5. Krewitt W, Schlomann B. Externe Kosten der Stromerzeugung aus erneuerbaren Energien im Vergleich zur Stromerzeugung aus fossilen Energieträgern, Report Deutsches Institut für Luft und Raumfahrt (DLR). 2006.

6. Frisson LL, Hofkens H, De Clercq K, Nijs J, Geeroms A. Cost effective recycling of PV modules and the impact on the environment, life cycle, energy payback time and cost. In Proceedings of 2nd World Conference on Photovoltaic Energy Conversion. Vienna, Austria, 1998; 2210-2213.

7. Voß A. Leitbild und Wege einer Umwelt- und Klimaverträglichen. Energieversorgung. In Energiepolitik HG Brauch (ed.). Springer Verlag: Berlin, 1997.

8. Swiss Federal Laboratories for Materials Testing and Research EMPA. ecoinvent Database v2.0, 2008. Available at: http://www.ecoinvent.org

9. Consultants PRé. SimaPro 7, Multi User 7.0.1. 2009.

10. Reich NH. Analysis of direct and indirect greenhouse gas emissions from crystalline silicon photovoltaic systems. In Proceedings of 24th European Photovoltaic Solar Energy Conference and Exhibition, Hamburg, Germany, Sinke W, Ossenbrink H,
Helm P (eds). WIP-Renewable Energies: Munich, Germany, 2009; 4521-4524.

11. Wild-Scholten MJd, Alsema EA, Fthenakis VM, Agostinelli G, Dekkers H, Roth K, Kinzig V. Fluorinated greenhouse gases in photovoltaic module manufacturing potential emissions and abatement strategies. In Proceedings of 22nd European Photovoltaic Solar Energy Conference, Willeke G, Ossenbrink H, Helm P (eds). WIPRenewable Energies: Munich, Germany, 2007; 1356-1366.

12. Schottler M, Wild-Scholten MJd. Carbon footprint of PECVD chamber cleaning. Photovoltaics International 2008; 1(2): 64-69.

13. http://www.pvcycle.org/

14. Müller A, Wambach K, Alsema EA. Life cycle analysis of a module recycling process. In Proceedings of 20th European Photovoltaic Solar Energy Conference, W, Hoffmann J-L, Bal H, Ossenbrink W, Palz P Helm (eds). WIP Renewable Energies: Barcelona, Spain, 2005.

15. Bombach E, Röver I, Müller A, Schlenker S, Wambach K, Kopecek R, Wefringhaus E. Technical Experience during thermal and chemical recycling of a 23 year old pvgenerator formerly installed on pellworm island. In Proceedings of 21st European Photovoltaic Solar Energy Conference, Poortmans J, Ossenbrink H, Dunlop E, Helm P (eds). WIP Renewable Energies: Dresden, Germany, 2006.

16. Súri M, Huld T, Dunlop E, PV-GIS: a web-based solar radiation database for the calculation of PV potential in Europe. International Journal of Solar Energy 2005; 24: 55-67.

17. Wild-Scholten MJd, Alsema EA, Excel file, ECN, Environmental life cycle inventory of crystalline silicon photovoltaic module production. Available at: http:// www.ecn.nl/docs/library/report/2006/c06002-LCI_datacSiPV-pub-v1.xls Report ECN, 2006.

18. International Energy Agency. World Energy Outlook 2008. OECD/IEA: Paris, France, 2008.

19. Wolfsegger C, Fraile D, Teske S, Latour M, Bitter M, Limet F, Lenoir S, Elamine W, Diaz T, Cavalli I, Yoon K-H, Coequyt J, Hennessey S, Blaesteros AR, Yang A, Fitzpaterick C, Wakeham M, Solar Generation V2008: solar electricity for over one billion people and two million jobs by 2020 , Report EPIA/Greenpeace, 2008.

20. 1366 Technologies Inc., PV market, http://1366tech. com/v1/index.php?option=com_content\&task=view\&id= 24\&Itemid=60 [Accessed on 16 February 2010]. 2009.

21. Herron, J, Huge demand for inverters. Photon International 2010. 70-71.

22. Maycock P, PV News: p. (several issues over the years 1995-2002).

23. Lysen EH, Daey C, Ouwens, Energy effects of the rapid growth of PV capacity and the urgent need to reduce the energy payback time. In Proceedings of 
PV in Europe, 7-11 October 2002, From PV Technology to Energy Solutions (eds). Rome, Italy, 101-104.

24. Richards BS, Watt ME, Permanently dispelling a myth of photovoltaics via the adoption of a new net energy indicator. Renewable and Sustainable Energy Reviews 2007; 11(1): 162-172.

25. Krauter $\mathrm{S}$, Rüther R, Considerations for the calculation of greenhouse gas reduction by photovoltaic solar energy. Renewable Energy 2004; 29(3): 345-355. 